\title{
Burdur yöresinde bir sağmal süt sığırı (simental) işletmesinde gözlenen ayak hastalıklarının incelenmesi
}

\author{
Özlem Şengöz-Şirin ${ }^{1}$, Ayşegül Önür ${ }^{1}$, Furkan Şavklıyıldız ${ }^{1}$ \\ ${ }^{1}$ Burdur Mehmet Akif Ersoy Üniversitesi, Veteriner Fakültesi, Cerrahi ABD, Burdur/TÜRKIYE
}

\author{
Anahtar Kelimeler: \\ ayak hastalıkları \\ siğ1r \\ tirnak \\ topallik
}

Key Words:

foot diseases

cattle

hoof

lameness

Gelis Tarihi : 21.02 .2021

Kabul Tarihi : 14.03 .2021

Yayin Tarihi : 30.04 .2021

Makale Kodu : 884378

Sorumlu Yazar:

(sengozozlem@gmail com)

ORCID

Ö. SENGÖZ ȘIRIN : 0000-0002-2232-6349

A. ÖNÜR : 0000-0003-1352-1959
Ö. ŞENGÖZ-ŞIRIN

F. SAVKLIYILDIZ : :0000-0002-8057-8798

\begin{abstract}
ÖZ
Çalıșmada Burdur ilinin Kemer ilçesinde sağmal bir işletmede bulunan Simental ırkı sığırların ayak hastalıklarının belirlenmesi ve lezyonlu ayakların tedavi edilmesi, koruyucu önlemlerin alınması ve efektif sürü sağlığının sağlanması amaçlanmıştır. Araştırma materyali olarak rutin tırnak kesimi yapılan 281 adet, farklı yaş ve ağırlıktaki Simental ırkı sığırlar kullanıldı. İncelenen olgularda 7 hayvanda sadece tırnak deformitesi, 104 vakada ayak hastalığı görülürken 165 olguda da tırnak deformitesi ile birlikte ayak hastalı̆̆1 saptandı. 221 adet deformasyon tespit edildi; olguların 78'i yayvan ve geniş tırnak, 65'i düzenli uzamıs tırnak, 49'u tirbuşon tırnak, 16's1 makasvari tırnak, 12'si küt tırnak, 1'i gaga tırnak olarak saptandı. Ayak hastalığ1 gözlenen 269 sığırda toplam 578 adet lezyon tespit edildi. Belirlenen lezyonların 195'i subklinik laminitis, 198'i beyaz çizgi hastalığ1, 125'i çift taban oluşumu, 31'i tırnak çatlağı, 12'si yabanci cisim, 5'i ince taban oluşumu, 3'ü taban ucu ülseri, 2'si interdigital dermatitis, 2'si taban ülseri, 1'i digital dermatitis, 1'i ökçe erozyonu, 1'i ökçe ülseri, 1’i ökçeden tırnak ayrılması ve 1'i podoartritis purulenta idi. Elde edilen veriler doğrultusunda hasta sahipleri ayak hastalıklar1 ve tırnak deformasyonları hakkında bilgilendirildi ve işletmenin yönetimsel bazda bazı değişiklere gitmesi gerektiği belirtildi.
\end{abstract}

\section{Investigation of foot diseases observed in dairy farm (simmental) in Burdur province}

\begin{abstract}
In the study, it was aimed to determine the foot diseases of the Simmental breed cattle in a dairy farm, which in Kemer town of Burdur city and to take preventive measures together with the treatment of the lesioned hoofs and to ensure effective herd health. As the research material, 281 Simmental breeds, cattle of different ages and weights, which were routinely trimming toenails, were used. There were only digital deformities in 7 claws and only foot diseases in 104 claws. Foot diseases with digital deformities were seen in 165 cattle. Classification of the deformities and diseases were as follows; splay claw in 78 , regularly elongated claw in 65 , corkscrew claw in 49 , scissor claw in 16 , blunt claw in 12 , beak claw in 1 cases. . In this study, a total of 578 lesions were identified in 269 cattle with foot disease. 195 of the identified lesions were subclinical laminitis, 198 white line disease, 125 occurrence of twin solear, 31 fissure ungulae, 12 foreign body invasion, 5 thin base formation, 3 base tip ulcers, 2 interdigital dermatitis, 2 solea ulcers 1 digital dermatitis, 1 heel erosion, 1 heel ulcer, 1 nail detachment from the heel and 1 podoarthritis purulenta. In line with the data obtained, the owners were informed about foot diseases and nail deformities, and it was stated that the business had to make some changes on a managerial basis.
\end{abstract}

\section{GİRIŞ}

Dünyanın farklı ülkelerinde gerçekleştirilen epidemiyolojik çalışmaların sonuçlarına göre topallık, süt sığırlarında mastitis ve infertiliteden sonra ciddi ekonomik kayiplara sebep olan en önemli sağlık problemlerinden biridir (1-3). Ülkemizde modern süt sığırcılığı işletmelerinin yaygınlaşması ile birlikte ayak hastalıklarının sı̆̆ırlarda görülme oranı artmıştır. Örneğin, İngiltere'de, ayak hastalıkları gözlenen ineklerin oranının (insidans) 1957/58 yıllarında \%4, 1980'li yılların başında \%25 ve 1990 'l y1llarda ise \% 54.6 civarında olduğu belirtilmektedir (4). Yapılan araştırmalarda süt sığırlarında görülen ayak hastalıkları insidansının \%1-25 oranları arasında değiştiği bazı kaynaklarda ise $\% 30$ ve üzerinde olduğu bildirilmiştir (1). Yapılan bir araştırma, ayak ve tırnak lezyonlarının modern sayılabilecek ve çok bakımlı işletmelerde bile $\% 18.3$ oranında görüldüğünü belirtmektedir (5). Ayak hastalıkları insidans1; Güney Kore'de \%0.3-3, Avustralya'da \%3.7, ABD'de \%6.6, Pakistan'da $\% 7.6$, İrlanda'da \%9.5, Fransa'da \%10.9, İsviçre'de \%16.4 ve İngiltere'de \%17.4 şeklindedir (6).

Ayak hastalıklarının sebep olduğu öncelikli ekonomik kayıplar canlı ağırlık kaybı, ağırlık artışında azalma, üretimden erken ç1kma, tedavi giderleri, laktasyon süresi ile süt veriminde azalma ve infertilite şeklindedir $(3,7,8,9)$. Ayak hastalığ1 saptanan sığırlarda sağlıklı olan sığırlara oranla günlük süt verimi 1,12 kg ile 3,1 kg arasında azalmakta, gebe kalma süreleri 12 gün daha 
uzamakta ve \%1,17'si sürüden çıkarılmaktadır (10). Birçok araștırmacı sığır ayak hastalıklarının büyük oranda kültür 1rk1 sığırlarda görüldüğünü vurgulamışlardır $(1,7,11,12)$.

Sı̆̆ırlarda görülen ayak hastalıklarının bildirilen birçok sebebi bulunmaktadır. Uygun olmayan koşullarda barındırma, iyi beslememe, mevsim, yaş, 1rk ve cinsiyet, gebelik ve laktasyon ayak hastalıklarının şekillenmesinde önemli rol oynamaktadirlar $(3,12)$.

Bu çalışmada Burdur ilinin Kemer ilçesinde sağmal bir işletmede bulunan Simental 1rk1 sığırların ayak hastalıklarının belirlenmesi ve lezyonlu ayakların tedavisi, koruyucu önlemlerin alınması ve efektif sürü sağlığ1 amaçlanmıştır.

\section{GEREÇ ve YÖNTEM}

Araştırma materyali olarak Burdur ilinin Kemer ilçesinde 1100 başlik sağmal bir işletmede bulunan rutin tırnak kesimi yapılan 281 adet, Simental 1rk, farklı yaş ve ağırlıktaki sığırlar kullanıldı. Araştırma Kasım ayında gerçekleştirildi. İşletmenin fiziki yapısı, ahırların durumu, temizliği, kapasitesi ve hayvanlarin beslenme programı incelendi. Issletme sahibine ayak hastalıkları ve tırnak deformasyonlarinın nedenleri ve alınabilecek önlemler, tırnak kesim programı ve tekniği ile ilgili bilgiler verildi.

Bütün hayvanların ayakları mekanik olarak temizlendi ve ortopedik tırnak kesimi yap1ld1. Ortopedik tırnak kesimi yap1lan ayaklarda canli ve cansiz tırnak lezyonları ortaya çıkarıldı. Lezyonun durumuna göre uygun sağaltım yöntemleri uyguland. Hayvanların anamnez ve klinik muayeneleri ile elde edilen veriler "Hasta Muayene Formlarına" işlendi (Şekil 1) ve istatistiksel olarak değerlendirilmek üzere kayıt altına alındi.

\section{BULGULAR}

İşletmenin her yerinde zeminin kilitli parke taşı olduğu, hayvanların yataklı̆̆1 olmadığı, padok içinde serbest dolaştıkları ve ek gezinti alanları olmadığ1 görüldü ancak bulunan alanın hayvan yoğunluğu için yeterli olduğu belirlendi. Bazı padoklarda dışkı ve idrar için kanalların bulunduğu bir kismında bu kanalların bulunmad1$\breve{g} 1$, haftada bir veya iki haftada bir kepçe ile temizlendiği öğrenildi. İşletmede önceden ayak banyolarının bulunmadı̆̆ı yapılan düzenleme ile tüm sığırların her gün sağım Öncesi ve sonrasi ayak banyolarından geçişinin sağlandığ1 öğrenildi. Siğırların ortalama süt veriminin 27 litre olduğu ve en son tırnak kesiminin beş ay önce yapıldığ1, işletmenin geçmişte digital dermatit ile mücadele ettiği ve alınan önlemler ile bu problemlerin azaldığı bilgisi alındı.

Araştırmada ayak hastalıkları olarak; taban ülseri (Şekil 2), ökçe ülseri (Şekil 3), tırnak çatlağ1 (Şekil 4) ve beyaz çizgi hastalığ1 (Şekil 5) gibi hastalıklar ile tırnak deformasyonlanı olarak; yayvan ve geniş tırnak (Şekil 6), küt tırnak (Şekil 7), makasvari tırnak, tirbuşon tırnak olguları gözlemlendi.

Hayvanların muayenesinde 281 baş sı̆̆ırın 7'sinde $(\% 2,49)$ sadece tırnak deformasyonu, 165 'inde $(\% 58,72)$ tirnak deformasyonu ile birlikte ayak hastalığ1, 104'ünde $(\% 37,01)$ ise sadece lezyonlu ayak hastalığ1 saptand1. 281 baş sığırdan 5 'inde $(\% 1,78)$ ne tirnak deformasyonu ne de ayak hastalığ1 bulunduğu görüldü. Tirnak kesimi yapılan 281 sığırdan 35 'inde $(\% 12,46)$ topallik tespit edildi.



Şekil 1. Hasta muayene formu 




Şekil 2. Taban ülseri

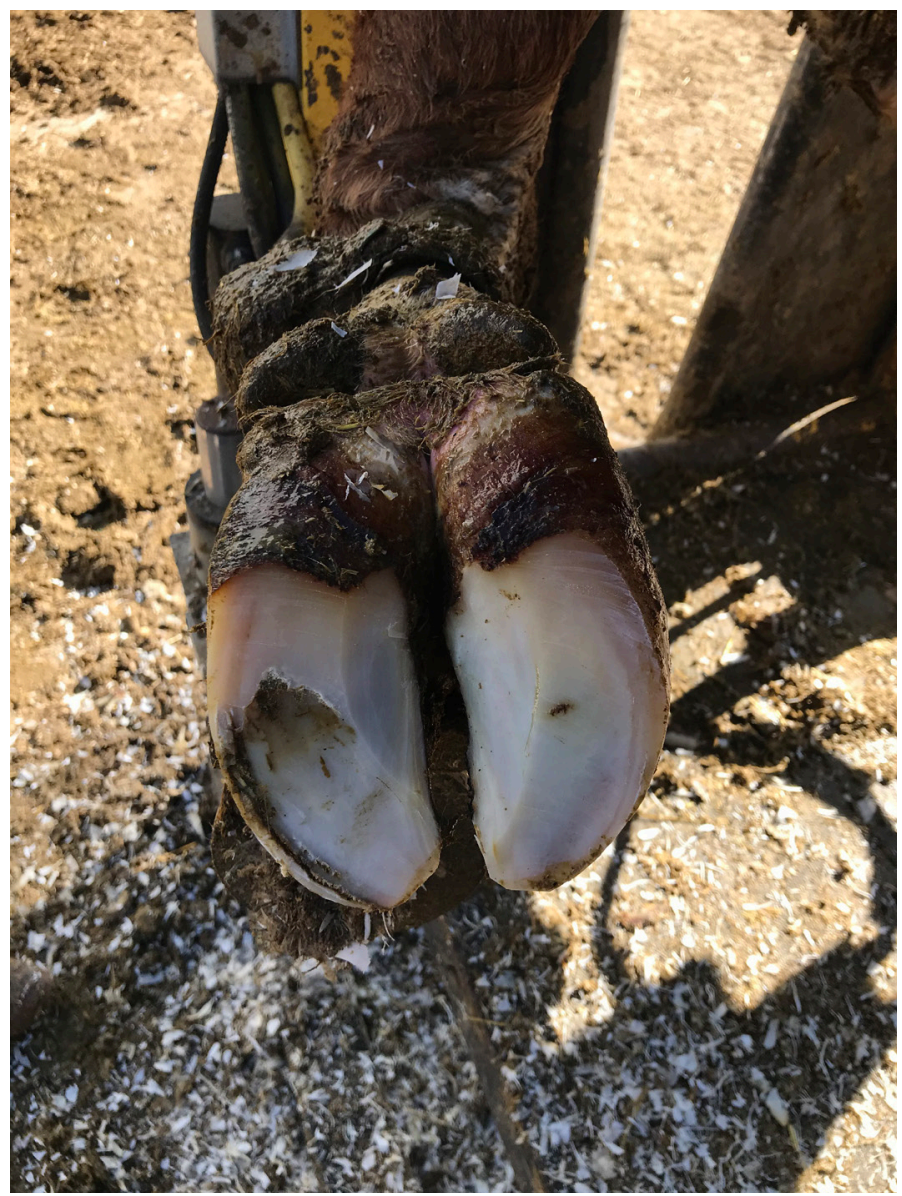

Şekil 4. Beyaz çizgi hastalığ

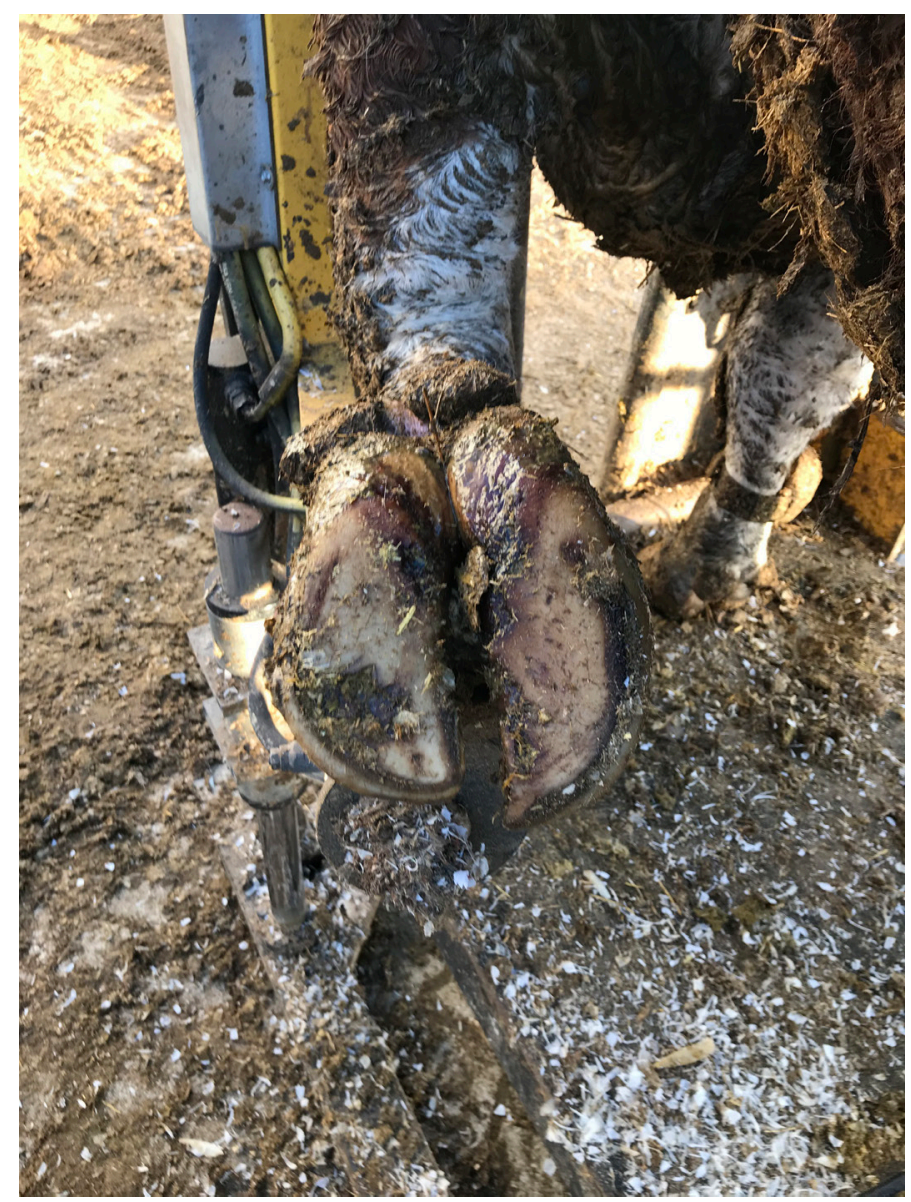

Şekil 3. Ökçe ülseri



Şekil 5. Tirnak çatlağı 




Şekil 6. Geniş ve yayvan tırnak

Ayak hastalığı gözlenen 269 sığırda toplam 578 adet lezyon tespit edildi. Belirlenen lezyonların 195'ini $(\% 33,74)$ subklinik laminitis, 198'ini $(\% 34,26)$ beyaz çizgi hastalığı, 125'ini $(\% 21,63)$ çift taban oluşumu, 31'ini $(\% 5,36)$ tırnak çatlağ1, 12 'sini $(\% 2,08)$ yabance cisim, 5 'ini $(\% 0,87)$ ince taban oluşumu, 3'ünü $(\% 0,52)$ taban ucu ülseri, 2'sini $(\% 0,35)$ interdigital dermatitis, 2'sini $(\% 0,35)$ taban ülseri, 1'ini $(\% 0,17)$ digital dermatitis, $1^{\prime}$ ini $(\% 0,17)$ ökçe erozyonu, 1 'ini $(\% 0,17)$ ökçe ülseri, 1 'ini $(\% 0,17)$ ökçeden tırnak ayrılması ve 1 'ini $(\% 0,17)$ podoartritis purulenta oluşturdu.

Ayak hastalığ1 tespit edilen 269 baş hayvanda lezyonların ön ve arka ayaklarda görülme oranları ön ayaklarda $\% 63,23$ (ön sağ \%29,66, ön sol \%33,57), arka ayaklarda \%36,77 (arka sağ $\% 18,38$, arka sol \%18,38) olarak belirlendi. Lezyonlar ön ayak medial tırnakta $379(\% 53,23)$, lateral tırnakta $333(\% 46,44)$, arka ayak medial tırnakta $158(\% 38,16)$, lateral tırnakta 256 $(\% 61,84)$ olarak görüldü.

Tirnak deformasyonları tespit edilen 172 baş hayvanda 221 adet deformasyon tespit edildi; deformasyonlarin \%35,29'u yayvan ve geniş tırnak, \%29,41'i düzenli uzamış tırnak, $\% 22,17$ 'si tirbuşon tırnak, $\% 7,24$ makasvari tırnak, $\% 5,43$ 'ü küt tırnak, $\% 0,45$ 'i gaga tırnak olarak saptand, görülme oranlar1 ise; ön ayaklarda $130(\% 42,07)$ (ön sağ $\% 16,83$, ön sol $\% 25,24)$, arka ayaklarda $179(\% 57,93)$ (arka sağ $\% 28,80$, arka sol \%29,13) olarak tespit edildi.

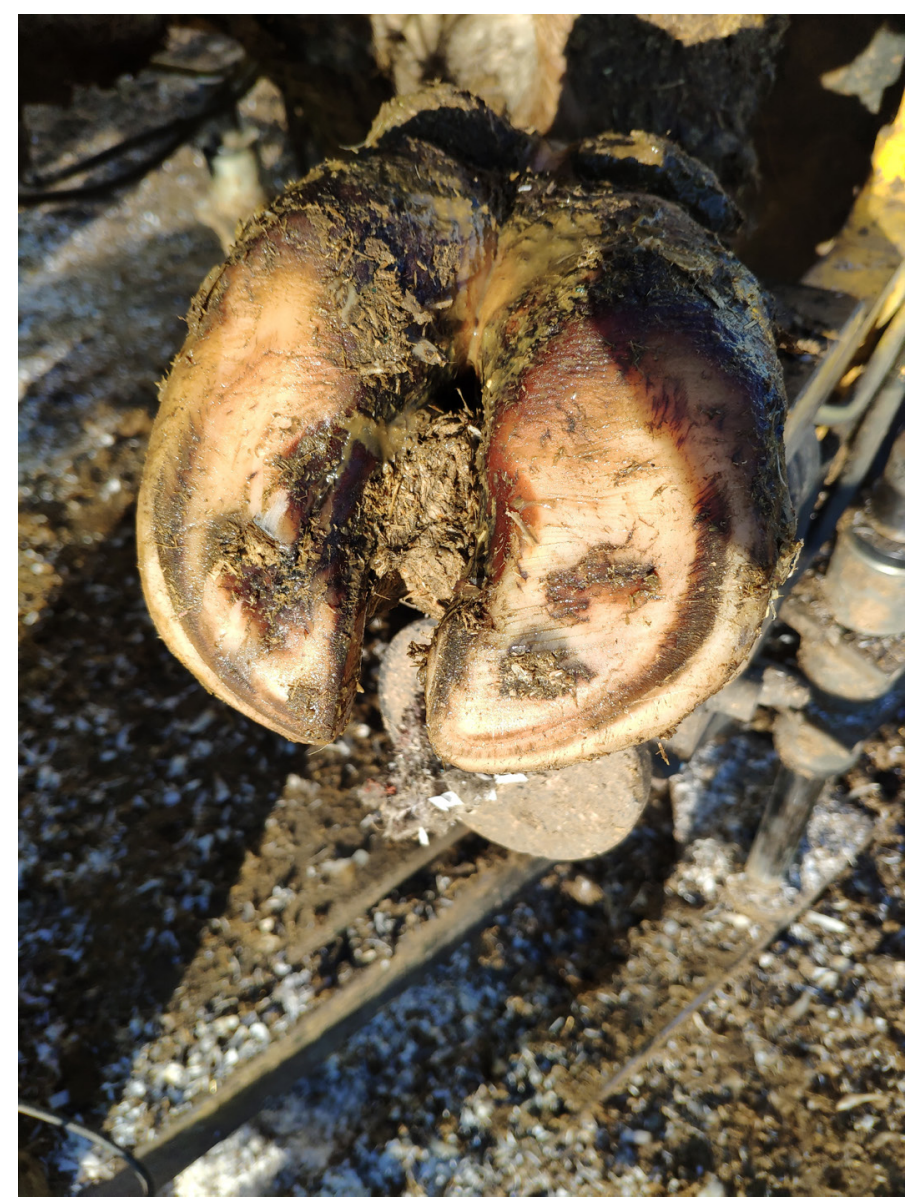

Şekil 7. Küt tırnak

\section{TARTIŞMA}

Sığır yetiştiriciliğinde ayak hastalıklarının önlenebilmesi için ahır 1sısının uygun olmasi, ahır zeminin kuru ve yumuşak olması, ayrıca zeminin düşmelere sebep olacak kadar kaygan olmaması gerekmektedir (13). Serbest dolaşımlı ahırlarda hayvanların başıboş gezinmeleri nedeniyle ahır zemininin dışkı ve idrarla daha fazla kirleneceği, dışk1 ve idrar içinde kalan ayaklarda hastalık riskinin artacağı vurgulanmıştır (14). İncelenen işletmede sığırların serbest dolaştığı, yataklık ve altlığın kullanılmadığı, idrar ve dışkı için yeterli kanalın bulunmadığı tespit edilmiştir ancak dışkı ve idrarın sık aralıklarla uzaklaştırıldığ bilinmektedir.

Bir tırnağın küçük, diğerinin büyük olması veya tırnak uzunluklarının eşit olmaması, vücut ağırlığının eşit dağılmamasına neden olur. Önlerde medial arkalarda ise lateral tırnaklar daha büyüktür (15). Çoğu kez ayak hastalıkları önlerde medial arkalarda ise lateral tırnaklarda oluşur $(15,16,17)$. Bu araştırmada lezyonlar ön ayak medial tırnakta $379(\% 53,23)$, lateral tırnakta $333(\% 46,44)$, arka ayak medial tirnakta $158(\% 38,16)$, lateral tırnakta 256 $\% 61,84)$ olarak görüldü. Araştırmanın sonuçları bu konuda daha önce yapılmış araştırmaların sonuçlarıyla paralellik göstermektedir $(1,10,18)$.

Tirnağın uzaması, bakımının yapılamaması, tırnakların kesilip düzeltilmemesi, ahır hijyeni ve zeminin durumu tırnakların değişimine ve bozulmasına sebep olur. Bunun sonucunda deforme tırnaklar oluşur. Deforme tırnaklar genetik faktörlerle de oluşabilir (19). Anteplioğlu ve Akın (1978)(20) özellikle kış aylarında uzun süre ahır bakımında hareketsiz kalmış inek- 
lerde aşırı tırnak uzamalarına bağlı yürüyüş bozukluklarının gözlendiğini belirtmişlerdir. Deforme tırnak yapılarının, tırnak hastalıklarının oluşması üzerine ciddi etkilerinin olduğu ifade edilmiştir. Yapılan bir çalışmada ülkemizdeki tırnak deformasyonlarının \% 25'in üzerinde olduğu bildirilmiştir (21). Tirnak deformitelerinin ayak hastalıklanı içerisinde \%58,72 gibi yüksek oranda görülmesi ayak hastalıklarının oluşmasında deforme tırnak yapısının önemli rol oynadığı ve bu durum bundan önceki araştırmacıların bulguları ile benzerlik göstermektedir $(10,13,18,22)$.

Laminitis çok faktörlü bir olaydır ve büyüme hızı, yaş, doğum, laktasyon, beslenme, davranış, barınma, mevsim, tırnak kesimi uygulamaları ve üreme bozuklukları ile ortaya çıkabilir (3). Karbonhidratlarca zengin yemlerin fazla miktarda verilmesi ile rumen asidozunun oluşması, $\mathrm{pH}$ düşmesi ve aşırı miktarda laktik asidin artması sonucunda laminitis meydana gelmektedir. Buna bağlı olarak da kornu üretimi etkilenerek deforme tırnak yapıları ve solea ülseri gibi ayak hastalıkları oluşmaktadır $(23,24,25)$. Subklinik laminitin, tek başına ülserler ve beyaz çizgi hastalığ1 gibi topallığa neden olabilen lezyonların önemli bir predispozan nedeni olduğu düşünülmektedir $(26,27)$. İngiltere ve Galler'in 4 bölgesinde 37 süt çiftliği üzerinde yapilan bir araştırmada, topallı̆ga neden olan 8645 lezyondan \% 40'ını taban ülserinin ve \% 29'unu beyaz çizgi lezyonlarının oluşturduğu gözlenmiştir (27).

Araştırma yapılan işletmedeki sığırlarda görülen lezyonların büyük çoğunluğunu, subklinik laminitisin $(\% 33,74)$, laminitisle alakalı beyaz çizgi hastalığının $(\% 34,26)$, çift taban oluşumunun $(\% 21,63)$ oluşturduğu gözlenmiştir. İşletmenin bir süredir rasyon ile ilgili sıkıntılar yaşadığı bilinmektedir dolayısıyla doğum sonrası sığırların süt veriminin arttırılması amaciyla karbonhidrat ve enerji bakımından zengin rasyonla beslenmesi, rasyonların dengeli hazırlanmamas1, ayrıca ahır zemininin sert olması ve sürekli idrar ve gübre ile kirli halde bulunması gibi sebeplerin laminitis, dolaylı ve doğrudan beyaz çizgi hastalığ1 ve çift taban oluşumunda artışa sebep olabileceği düşünülmektedir.

Ayak hastalıklarının ortak belirtisi hafiften şiddetliye değişen topallıklardır (28) Topallığın erken tespiti son derece önemlidir. Erken müdahaleye izin verir ve hafif ayak hastalıklarına göre neredeyse 3 kat daha fazla maliyete neden olan daha şiddetli ayak hastalıklarının önlenmesine katkıda bulunur (29). Belge ve ark., (2005)(26) çalışma sonuçlarına göre süt sığırlarında topallık insidansının \% 13 ile \% 58 arasında değişkenlik gösterdiğini saptamışlardır. Birçok yazar ayak hastalıklarının diagnoz öncesi ve sonrası, haftalar hatta aylar boyunca süt verimini düşürdüğünü rapor etmişlerdir $(30,31,32)$. Huxley (2013) (30) topal bir ineğin laktasyon başına 270 ila $574 \mathrm{~kg}$ daha az süt üretebileceğini özetlemiş ve topallı̆̆1 tanımlamanın farklı yollar1 ve analiz için kullanılan metodolojiler nedeniyle literatürde verilen çok çeşitli değerleri karşılaştırmanın zorluğunun altını çizmiştir (29). Amory ve ark. (2008)(33), İngiltere ve Galler'deki 30 süt ineği çiftliğinde spesifik lezyonlar ve süt üretimi arasındaki ilişkiyi analiz ettikleri çalışmada taban ülseri ve beyaz çizgi hastalığına bağlı süt kaybını sırasıyla 1,5 ve $0,8 \mathrm{~kg} /$ gün olarak tahmin etmişlerdir ve bu laktasyon boyunca sirasıyla 574 ve $369 \mathrm{~kg}$ toplam kayba neden olmaktadir.
Tirnaklardaki lezyonları önlemek ve ayak simetrisinin ve şeklinin düzeltilmesi ve korunmasıyla yürüyüşü iyileştirmek için tırnak kesimi yapılır, bu da ağırlığın doğru dağılımını sağlar. Tirnak bozukluklarının neden olduğu topallık, doğru tırnak kesimi ile tedavi edilebilir. Sağlıklı tırnaklarda tırnak kesimi, süt yağ1 ve süt proteini bileşimleri üzerinde önemli ölçüde etkilidir (34). İncelenen işletmede, tırnak kesimi yapılan 281 sığırda topallık oranının \%12,46 bulunması ile düzenli tırnak kesiminin topallık görülme oranındaki azalmaya katkı sağladı̆̆ı bilgisi desteklemektedir. Yetiştiriciler, işletmelerinde ayak hastalıklarının hiç olmamasını temenni etseler de, hastalıkların görülmesi kaçınılmazdır. Bu sebepten dolayı sürüde bulunan sığırların topallık puanlarına (1, 2, 3, 4 ve 5) göre ideal oranlarinin sirasiyla $\% 75, \% 15, \% 9, \% 0.5$ ve $\% 0.5$ seviyelerinde olması önerilmektedir (4).

\section{SONUÇ}

Elde edilen veriler doğrultusunda hasta sahipleri ayak hastalıkları ve tırnak deformasyonları hakkında bilgilendirildi ve işletmenin yönetimsel bazda bazı değişiklere gitmesi gerektiği belirtildi.

\section{BEYANNAMELER}

\section{Etik Onayı}

Uygulanamaz.

\section{Çıkar Çatışması}

Yazarlar, herhangi bir çıkar çatışması beyan etmemektedir.

\section{Yazar Katkıları}

Fikir, Kavram ve Tasarım: Ö Şengöz-Şirin, A Önür, F Şavklıyıldız Veri Toplama ve Analiz: Ö Şengöz-Şirin, A Önür, F Şavklıyıldız Makalenin Yazımı: Ö Şengöz-Şirin, A Önür, F Şavklıyıldız Eleştirel İnceleme: Ö Şengöz-Şirin, A Önür, F Şavklıyıldız

\section{Veri kullanılabilirliği}

$\mathrm{Bu}$ çalışmanın bulgularını destekleyen veriler makul talep üzerine sorumlu yazardan temin edilebilir.

\section{KAYNAKLAR}

1. Atasoy N. Erzurum Yöresinde Süt Sığırlarında Görülen Ayak Hastalıklarının İnsidansı ve Bunların Sağaltımı. Yüzüncü Y1l Üniversitesi Vet Fak Derg. 2003;14: 1-5.

2. Becker J, Steiner A, Kohler S, Koller-Bähler A, Wüthrich M, Reist M. Lameness and foot lesions in Swiss dairy cows: I. Prevalence. Schweiz Arch Tierheilkd. 2014;156:71-8.

3. İzci C. Sığırlarda Ayak Hastalıkları ve Topallık Kontrolü. Konya: Selçuk Üniversitesi Basımevi; 2018. p. 1-7.

4. Yaylak E. Süt Sığırlarında Topallık ve Topallığın Bazı Özelliklere Etkisi. Hayvansal Üretim 2008;49:47-56.

5. Şındak N, Keskin O, Selçukbiricik H, Sertkaya H. Şanlıurfa ve Yöresinde Sığır Ayak Hastalıklarının Prevalansı. Yüzüncü Y1l Üniversitesi Veteriner Fakültesi Dergisi 2003;14:14-18.

6. Yalçın C, Sarı̈̈zkan S, Yıldız AŞ, Günlü A. Burdur, Kırklareli ve Konya İl'lerindeki süt sı̆̆ırcıllğg işletmelerinde ayak hastalıklarından kaynaklanan finansal kayılar. Ankara Üniver- 
sitesi Vet Fak Derg. 2010;57:99-104.

7. Sağlıyan A, Ünsaldı E. Tunceli ve Yöresindeki Suğırlarda Karşılaşılan Ayak Hastalıklarının İnsidansı Üzerine Gözlemler. F1rat Üniversitesi Saglık Bilimleri Dergisi 2002;16:47-56.

8. Kamiloğlu A. Çiftlik Hayvanlarında Ayak Hastalıkları. 1. Bask1. Ankara: Medipres; 2014.

9. Cruz EA, Fischer V, Passos LT, Porciuncula GC, Stumpf MT, Werncke D, Santos CS. Effects of type of lesion and trimming on short-term behavior of grazing dairy cows. R. Bras. Zootec. 2017;46(4):280-285.

10. Yurdakul İ, Şen İ. Sivas ve Yöresinde Suğır Ayak Hastalıkları Prevalansının Belirlenmesi. Harran Üniversitesi Veteriner Fakültesi Dergisi 2018;7:51-55.

11. Canpolat İ, Bulut S. Elazı̆̆ ve çevresinde görülen ayak hastalıklarının insidansı üzerine gözlemler. Firat Üniversitesi Sağlık Bilimleri Dergisi 2003;17:155-160.

12. Keskin E, Durmuş AS. Gaziantep ve Yöresinde Gözlenen Sığır Ayak Hastalıklarının İnsidansı ve Tedavileri Üzerine Gözlemler. Firat Üniversitesi Sağlık Bilimleri Dergisi 2016;30:181-186

13. Yayla S, Aksoy Ö, Kılıç E, Cihan M, Özaydın İ, Ermutlu CŞ. Kars ve yöresinde sığırların bakım ve barındırma koşulları ile ayak hastalıkları arasındaki ilişkinin değerlendirilmesi. Harran Üniversitesi Veteriner Fakültesi Dergisi 2012;1:22-27.

14. İstek Ö. Muş Yöresindeki Sığırlarda Görülen ayak Hastalıklarının Prevalansı Üzerine Çalışmalar, Doktora Tezi, Firat Üniversitesi Sağlık Bilimleri Enstitüsü, Elazığ, 2004.

15. Ünsaldı E, Durmuş AS. 1994-1998 yılları arasında kliniğimize gelen sığırlarda gözlenen ayak hastalıkları ve sağaltımları. Frrat Üniversitesi Sağlık Bilimleri Dergisi 1999;13:405-412.

16. Yavru N, Koç Y, Elma E, Erer H, Özkan K, İzci C, Kaya Z. Konya bölgesinde sığır topallıklarına neden olan ayak hastalıkları üzerine radyolojik ve histopatolojik incelemeler. Selçuk Üniversitesi Veteriner Fakültesi Dergisi 1992;8:3-8.

17. Yakan S. Ağrı İlinde Sı̆̆ırlarda Ayak Hastalıkları Prevalansının Belirlenmesi. Harran Üniversitesi Veteriner Fakültesi Dergisi 2018;7:207-212.

18. Özcan S, Pamuk K. Afyonkarahisar ve Çevresinde Siğır Ayak Hastalıklarının Prevalansı. Kocatepe Vet Derg. 2009;2:1519.

19. Yavru N, Özkan K, Elma E. Ayak Hastalıkları ve Ortopedi. SÜ. Vet. Fak. Konya. Ankara: Basım Ofset Matbaası. 1989.

20. Anteplioglu H, Akın F. Kliniğimizde Siğırlarda Rastladığımız Topallıklar ve Bunların Nedenlerine Toplu Bir Bakış. Ankara Üniversitesi Vet Fak Derg. 1978;25:144-162.

21. Ayhan HD. Elazı̆̆ ve Adıyaman Yöresinde Siğırlarda Ayak Hastalıkları Prevalansının Araştırılması, Yüksek Lisans Tezi, Fırat Üniversitesi Sağlık Bilimleri Enstitüsü, Elazı̆̆, 2019.
22. Canpolat İ, Bulut S. Elazı̆̆ ve Çevresinde Sı̆̆ırlarda Görülen Ayak Hastalıklarının Insidansı Üzerine Gözlemler. F.Ü. Sağllk Bil. Dergisi. 2003;17(3):155-160.

23. Keskin E. Gaziantep ve Yöresinde Gözlenen Sığ1 Ayak Ayak Hastalıklarının İnsidansı ve Tedavileri Üzerine Gözlemler, Yüksek Lisans Tezi, Fırat Üniversitesi Sağlık Bilimleri Enstitüsü, 2016.

24. Lean IJ, Westwood CT, Golder HM, Vermunt JJ. Impact of Nutrition on Lameness and Claw Health in Cattle. Livest Sci. 2013;156:71-87.

25. Vermunt JJ. "Subclinical" laminitis in dairy cattle. N Z Vet J. 1992;40:133-138.

26. Belge A, Bakır B, Gönenci R, Ormanc1 S. Subclinical Laaminitis in Dairy Cattle: 205 Selected Cases. Turk J Vet Anim Sci. 2005;29:9-15.

27. Shearer JK, Amstel SR. Pathogenesis snd Treatment of Sole Ulcers and White Line Disease. Vet Clin North Am Food Anim Pract. 2017;33:283-300.

28. Görgül OS, Kahraman MM, Çeçen G, Akkoç A, Gül NY, Sevimli A. Sı̆̆ırlarda digital interdigital dermatitis'lerde Klinik Tanı, Sağaltım ve histopatolojik bulgular. Uludağ Univ J Fac Vet Med. 2002;21:115-124.

29. Charfeddine N, Pérez-Cabal MA. Effect of claw disorders on milk production, fertility, and longevity,and their economic impact in Spanish Holstein cows. Jt Meet Abstr Am Dairy Sci Assoc. 2017;100:1-13.

30. Huxley JL. Impact of lameness and claw lesions in cows on health and production. Livest Sci. 2013;156:64-70.

31. Warnick LD, Janssen D, Guard CL, Gröhn YT. The Effect of Lameness on Milk Production in Dairy Cows. Jt Meet Abstr Am Dairy Sci Assoc. 2001;84:1988-1997.

32. Green LE, Hedges VJ, Schukken YH, Blowey RW, Packington AJ. The Impact of Clinical Lameness on the Milk Yield of Dairy Cows. Jt Meet Abstr Am Dairy Sci Assoc. 2002;85:2250-2256.

33. Amory JR, Barker ZE, Wright JL, Mason SA, Blowey RW, Green LE. Associations between sole ulcer, white line disease and digital dermatitis and the milk yield of 1824 dairy cows on 30 dairy cow farms in England and Wales from February 2003-November 2004. Prev Vet Med 2007;83:381-391.

34. Kibar M, Çağlayan T. Effect of Hoof Trimming on Milk Yield in Dairy Cows with Foot Disease. Acta Sci Vet. 2016;44:1370. 